Report

\title{
Sex steroid receptor expression in 'carcinoid' tumours of the breast
}

\author{
C.A. Birsak, P.J.A. Janssen, C.C.J. van Vroonhoven, J.L. Peterse ${ }^{1}$ and Th.H. van der Kwast \\ Department of Pathology, Erasmus University, Postbox 1738, NL-3000 DR Rotterdam, The Netherlands; \\ ${ }^{\prime}$ Department of Pathology, the Netherlands Cancer Institute Amsterdam, The Netherlands
}

Key words: argyrophilic cells, androgen receptor, breast cancer, carcinoid, chromogranin A, estrogen receptor, Grimelius silver stain, progesterone receptor

\section{Summary}

Nine 'carcinoids' of the breast (argyrophilic carcinomas) were examined for the presence of estrogen receptor (ER), progesterone receptor (PR), and androgen receptor (AR), using immunohistochemistry. The tumours were selected on the basis of their histo-morphological appearance and positive Grimelius stain. All cases were immunoreactive for neuron-specific enolase (NSE). In one case the tumour cells were intensely chromogranin A positive. All cases were ER positive, while 5 cases expressed AR and 5 cases PR. Immunostaining for ER and simultaneous demonstration of argyrophilia or chromogranin A expression in chromogranin $\mathrm{A}$ positive argyrophilic carcinoid tumour of the breast provided further evidence that neuroendocrine cells in breast tumours express sex steroid receptors. The similarity in sex steroid receptor expression pattern in 'carcinoids' of the breast and the more common categories of breast cancer suggests an identical responsiveness to endocrine therapy.

\section{Introduction}

The term 'carcinoid tumour of the breast' is applied to tumours with the classical organoid histomorphological appearance of a 'carcinoid' [1]. These tumours almost entirely consist of argyrophilic cells. However, there is a lot of confusion surrounding these so-called carcinoid tumours of the breast. Features of neuroendocrine differentiation like argyrophilia may also be present in a variable proportion of tumour cells in conventional infiltrating ductal and lobular carcinomas [2-7]. Besides this, only few argyrophilic breast cancers express chromogra$\operatorname{nin} A[8]$ and there is little evidence of ectopic hormone production $[1,9]$. Now, the term 'carcinoma of the breast with neuroendocrine differentiation' is preferred for mammary tumours expressing neuron-specific enolase (NSE) and/or chromogranin irrespective of the histopathological growth pattern.

The responsiveness of the majority of ductal and lobular carcinomas to endocrine therapy is reflected by their frequent expression of ER and PR. Similarly, a large proportion of breast carcinomas contains AR $[10,11]$. Except for a few biochemical studies on ER protein $[4,12,13]$, no data are available on sex steroid receptor expression in (argyrophilic) tumours of the breast with neuroendocrine differentiation and the histological growth pattern of "carcinoid'. The aim of this study was to investigate the presence of ER, PR, and AR in the argyrophilic cells of these 'carcinoids' of the breast with a set of 


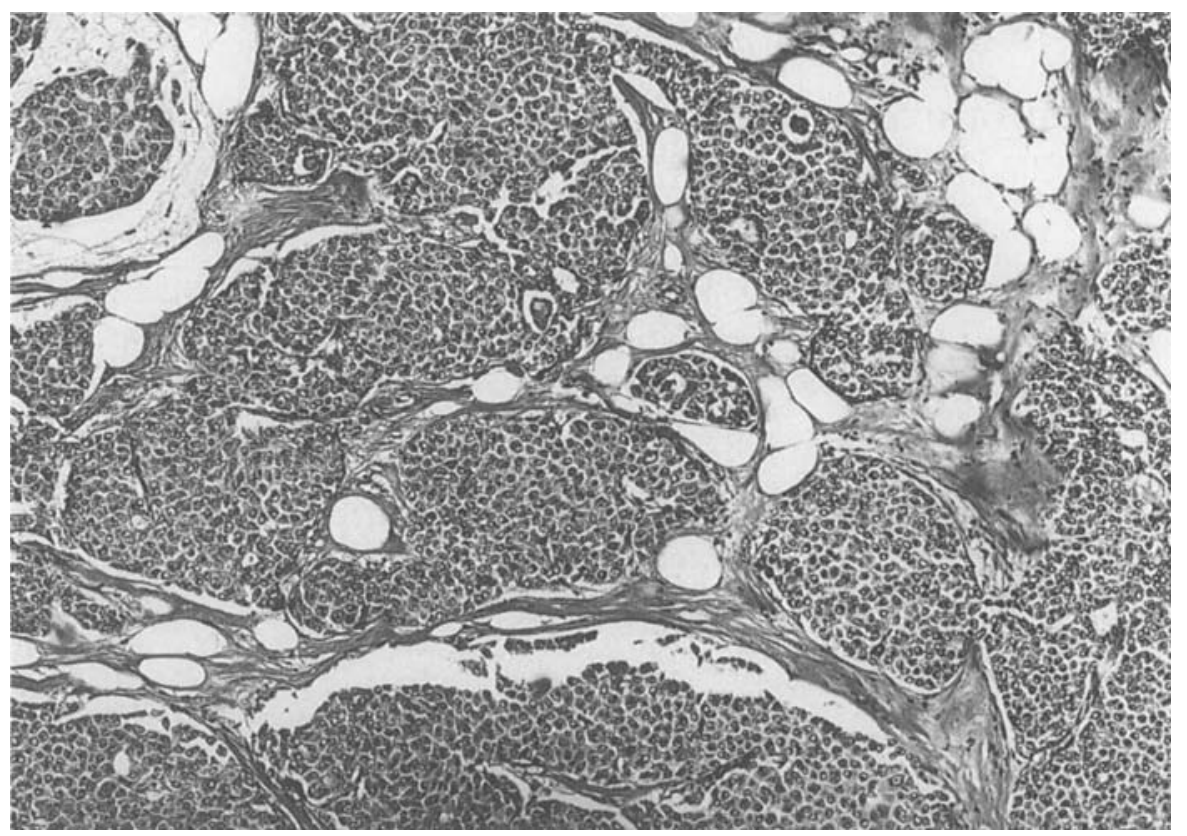

Figure 1. Case 7. Low power micrograph showing the typical histomorphological pattern of a carcinoid tumour. Tumour cells are arranged in larger solid fields. Hematoxylin-eosin. Objective $5 \times$.

specific monoclonal antibodies using immunohistochemistry. If the distribution of these sex steroid receptors among 'carcinoids' of the breast is similar to that found in conventional breast carcinomas, they could be regarded as well-differentiated breast cancers with a similar responsiveness to endocrine therapy.

\section{Materials and methods}

Paraffin-embedded specimens of 'carcinoid' tumours of the adult female breast fixed in phosphate buffered formaldehyde $4 \%$ ( $\mathrm{pH} 7.0$ ) were cut in $5 \mu \mathrm{m}$ thick sections. Eight cases were selected from the archives of the Dept. of Pathology of the Netherlands Cancer Institute in Amsterdam, and one additional case from the Dept. of Pathology of the University Hospital Dijkzigt in Rotterdam. All patients are still alive, two to five years after diagnosis. Expression of chromogranin A was detected with monoclonal antibody LK2H10 (Euro-diagnostica, Apeldoorn, The Netherlands), diluted 1:30 in phosphate buffered saline (PBS) solution ( $\mathrm{pH} 7.4$ ) followed by a routine streptavidin-biotin-perox- idase complex (ABC) method [14]. An additional case of a typical infiltrating ductal carcinoma with focal expression of chromogranin A was included in the study. Immunoreactivity with a rabbit antibody (diluted 1:800 in PBS) to neuron-specific enolase (Dakopatts, Copenhagen, Denmark) was also demonstrated with a routine $\mathrm{ABC}$ method.

\section{Immunostaining for $E R, P R$, and $A R$}

For detection of ER, PR, and AR, an antigen retrieval method was applied as described previously [15]. Briefly, the sections were dried at $60^{\circ} \mathrm{C}$ for 20 minutes, deparaffinized in xylene for 7 minutes, and immersed in $100 \%$ alcohol. Subsequently, endogenous peroxidase activity was blocked by treatment with $0.3 \%$ hydrogen peroxide in methanol for 20 minutes, and the sections were rinsed in distilled water. The slides were placed in a plastic box filled with $0.01 \mathrm{M}$ citrate buffer $\mathrm{pH} 6.0$, and processed in the microwave oven 3 times for 5 minutes at $700 \mathrm{~W}$. After cooling down to room-temperature, the slides were rinsed in PBS and pre-incubated for $15 \mathrm{~min}$ utes with normal goat serum (DAKO Glostrup, 


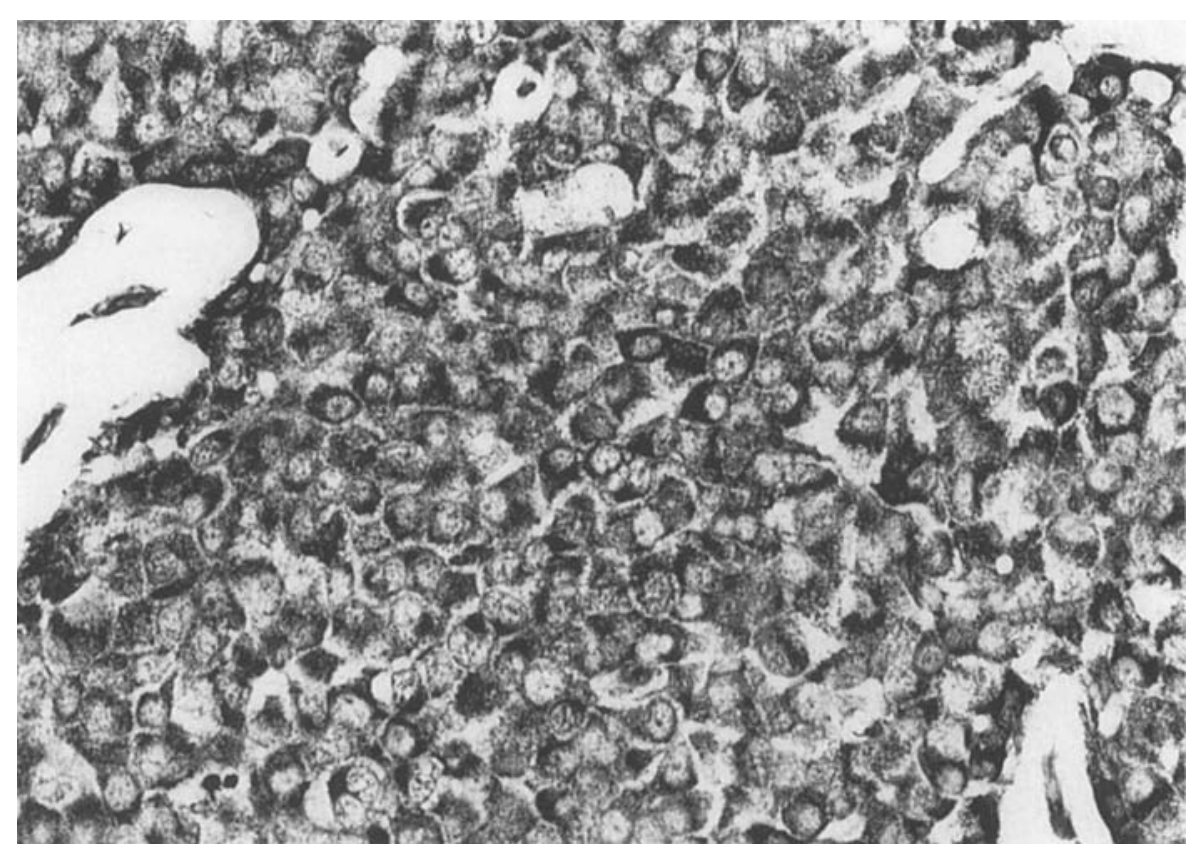

Figure 2. Argyrophilic granules in the cytoplasm (case 7). Most cells are positive. Grimelius silver stain. Objective $40 \times$.

Denmark), diluted 1:10 in PBS. Next, the sections were incubated overnight at $4^{\circ} \mathrm{C}$ with a monoclonal antibody against ER, PR (Immunotech, S.A.) [16], and monoclonal antibody F39.4 (Biogenex, CA, USA) directed against AR [17]. The specificity of F39.4 on paraffin sections for AR has been described earlier [18-20]. A standard $\mathrm{ABC}$ technique (DAKO Glostrup, Denmark) was used for visualization with $3,3^{\prime}$-diaminobenzidintetrahydrochloride (Fluka, Basel, Switzerland) as chromogen and $\mathrm{H}_{2} \mathrm{O}_{2}$ as substrate. As a positive control, breast carcinoma sections known to be positive for ER and PR were used. Prostatic tissue was used as a positive control for AR. As negative controls the primary antibodies specific for ER, PR, AR, and chromogranin A or neuron-specific enolase were substituted by PBS.

\section{Grimelius silver staining}

All cases were selected on the basis of their positive reaction with the Grimelius silver-stain essentially as described by Grimelius [21].

\section{Simultaneous detection of $E R$ and argyrophilic granules}

Immunostaining for ER was followed by the Grimelius stain. To intensify the argyrophilic staining reaction, the procedure was repeated by performing the cycle of incubations with Grimelius A and B solution up to 4 times five minutes. For visualization of ER by the bound ABC complex, the sections were immersed in freshly prepared 3-amino-9-ethyl-carbazole (AEC) solution yielding a red precipitate. After the Grimelius staining reaction the silver grain precipitate was amplified with an $0.1 \%$ (v/ v) sodium acetate solution containing $0.02 \% \mathrm{AuCl}_{3}$. This solution was kept on the slides for two minutes. Next, the non-specific metal-complex was removed by rinsing with $5 \%$ sodium-thiosulfate. The incubation with $\mathrm{AuCl}_{3}$ is probably based on a redox reaction. By this procedure the precipitated silver grains, linked to protein in neuroendocrine cells, assume a darker brown violet colour. In this way background staining was minimized without influencing the intensity of the AEC precipitate. As positive controls pancreas and lung tissue were used. 


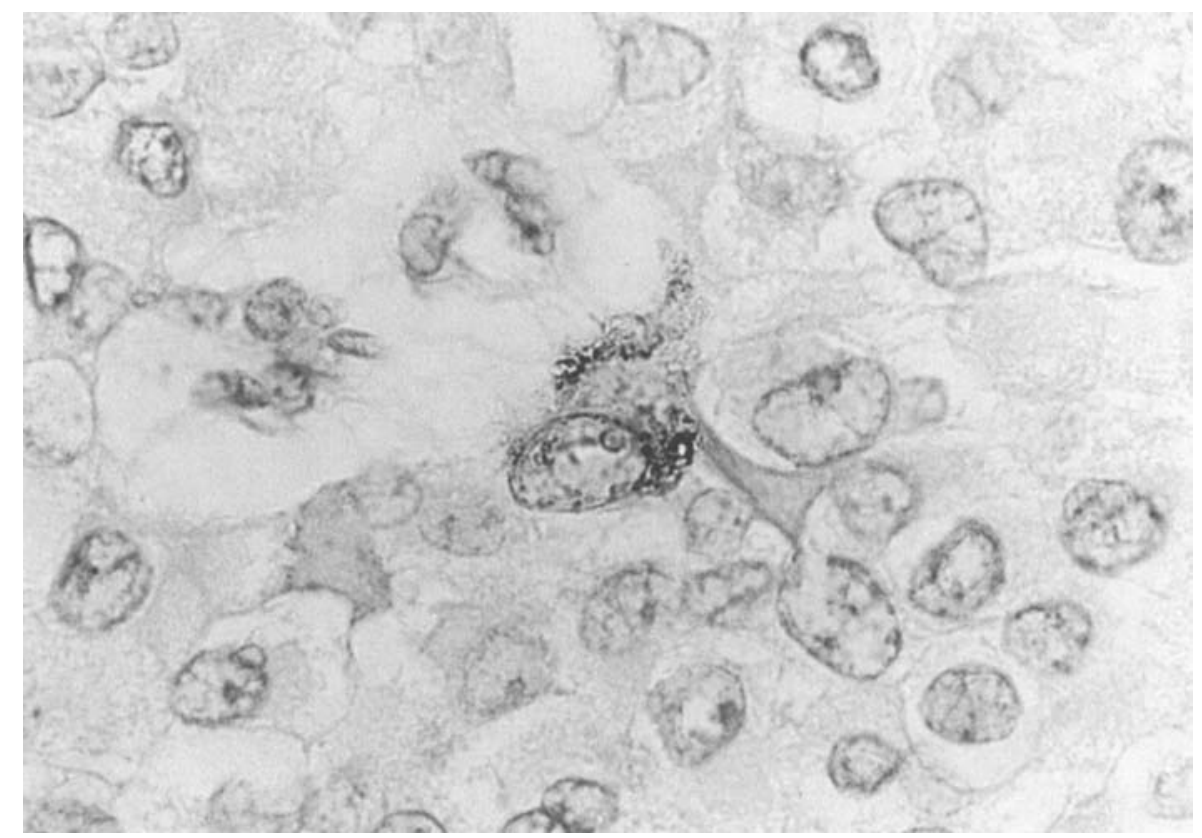

Figure 3. 'Carcinoid' tumour of the breast (case 7) immunostained for chromogranin A. Dispersed cells show immunoreactivity. Objective $100 \times$.

\section{Double-staining with chromogranin $A$ and ER}

In two cases of 'carcinoid' of the breast, a sequential immunostaining for ER and chromogranin A was performed. We first applied the antibody to chromogranin $A$ in a 1:30 dilution in PBS for 30 minutes, using alkaline phosphatase conjugated rabbit antimouse immunoglobulin (DAKO, Denmark) as secondary antibody. The sections were thoroughly washed and subsequently the procedure for ER detection was followed.

\section{Quantification}

The percentage of ER, $P R$, and AR positive tumour nuclei was calculated by counting the number of positive cells on a total of 300 cells in three different tumour areas. Tumours with a staining percentage less than $10 \%$ were regarded as negative. We designate our tumours as carcinoids, instead of argyrophilic tumours, to stress that they possess a classical endocrine appearance and are not mucinous tumours (Figure 1).

\section{Results}

In the nine 'carcinoids' of the breast we observed three staining patterns after the Grimelius reaction. Five tumours had a faint, rather homogenous granular staining. In three tumours we found scattered intensely positive cells in association with the faint, more diffuse, distribution pattern. One tumour almost entirely consisted of cells with a dense granular staining (Figure 2). In the latter tumour a positive chromogranin A staining was observed (Figure 3 ), while the remaining cases lacked immunoreactivity for this marker. In all nine cases a homogenous expression of neuron-specific enolase was observed, consistent with their putative neuro-endocrine differentiation.

All nine cases were ER positive (Figure 4), and in 5 cases a large proportion of $\mathrm{PR}$ positive tumour cells was present. The percentage of AR positive tumour cells within a tumour was on average lower than that of ER and PR. Three tumours expressed ER as the only receptor and 4 showed ER and PR as well as AR. In some tumours cytoplasmic staining for $P R$ and AR was noted. No stromal sex steroid receptor expression was noted. The distribution of 
ER, PR, and AR expression among the 9 'carcinoid' cases is given in Table 1 .

Double-staining performed on the 9 'carcinoid' tumours of the breast revealed a coexpression of both argyrophilic granules in the cell's cytoplasm and ER in the cell's nucleus. Similarly, in the one case with a positive chromogranin A staining, tumour cells expressing ER were also chromogranin A positive. The infiltrating ductal carcinoma with scattered neuroendocrine tumour cells showed occasional coexpression of chromogranin A and ER. However, the majority of the chromogranin A positive cells were ER negative.

\section{Discussion}

This paper demonstrates that all nine examined 'carcinoid' tumours of the breast express ER. Similarly, Chabon et al. [12] and others [4, 13] found very high levels of ER in breast carcinomas with argyrophilic tumour cells, using a biochemical ligand binding assay. This coincides with the high proportion of ER positive cases in well-differentiated infiltrating ductal carcinomas [22]. The lower number of $\mathrm{PR}$ and particularly AR positive tumour cells in argyrophilic carcinomas is also in line with the $P R$ and $\mathrm{AR}$ expression in infiltrating ductal carcinomas [10].

A controversial issue is whether (argyrophilic) 'carcinoids' of the breast should indeed be considered true neuroendocrine tumours similar to those encountered in other organs (e.g. those of the gastrointestinal tract). According to several authors, argyrophilia in breast tumours is not necessarily related to the neuroendocrine nature of a breast tumour. These authors related argyrophilia to the presence of milk proteins such as lactalbumin [2325]. However, these authors used the Sevier-Munger method for demonstration, while Cross [26], Toyoshima [7], and Fetissof et al. [2], did not find any evidence of argyrophilia in lactating breast tissue using the Grimelius procedure. They considered the possibility of lactalbumin as a cause of argyrophilia less likely. In an ultrastructural study Ferguson and Anderson [27], in accordance with Clayton [23], attributed the presence of dense core granules (DCG) to prelactational differentiation rather than neuroendocrine differentiation. The presence of dense core granules in normal nonpathological breast tissue confirms this finding $[2$, $4-6,27]$. Another argument against the view of "carcinoids' being a distinct type of breast tumour, is the finding of a high incidence ( $50 \%$ ) argyrophilia-positive 'normal breast cancers' by Taxy et al. [4]. Unlike this, Partanen and Azzopardi et al. [5, 6] only found an incidence of resp. $3.3 \%$ and $4.5 \%$. The frequently observed absence of chromogranin A (a constituent of neuroendocrine granules) expression in 'carcinoids' of the breast and the lack of con-

Table 1. Sex steroid receptor expression and Grimelius staining pattern in carcinoid tumours of the breast. Tumours with a staining percentage less than $10 \%$ were regarded as negative

\begin{tabular}{|c|c|c|c|c|c|c|c|}
\hline \multirow[t]{2}{*}{ Cases } & \multicolumn{2}{|c|}{ Grimelius } & \multirow[t]{2}{*}{$\operatorname{ER}(\%)$} & \multirow[t]{2}{*}{$\operatorname{AR}(\%)$} & \multirow[t]{2}{*}{$\operatorname{PR}(\%)$} & \multirow[t]{2}{*}{ Age } & \multirow[t]{2}{*}{ Stage } \\
\hline & Diffuse & Focal & & & & & \\
\hline 1 & + & - & 53 & 21 & 8 & 60 & T1N0 \\
\hline 2 & +++ & - & 11 & 2 & 10 & 68 & T1N0 \\
\hline 3 & ++ & - & 63 & 33 & 52 & 82 & T2NO \\
\hline 4 & $+/-$ & - & 51 & 0 & 8 & 89 & $\mathrm{~T} 2 \mathrm{~N} 1$ \\
\hline 5 & + & ++++ & 54 & 0 & 7 & 78 & $\mathrm{~T} 2 \mathrm{NO}$ \\
\hline 6 & ++ & $+++t$ & 33 & 0 & 6 & 83 & T2N1 \\
\hline $7^{1}$ & ++++ & - & 70 & 14 & 49 & 71 & $\mathrm{~T} 2 \mathrm{~N} 1$ \\
\hline 8 & +++ & - & 63 & 28 & 42 & 75 & T1N0 \\
\hline 9 & + & +++ & 26 & 19 & 13 & 70 & $\mathrm{~T} 2 \mathrm{NO}$ \\
\hline
\end{tabular}

\footnotetext{
' On average two chromogranin A positive cells, less than $1 \%$, per tumour field $(10 \times$ objective $)$ were seen.
} 


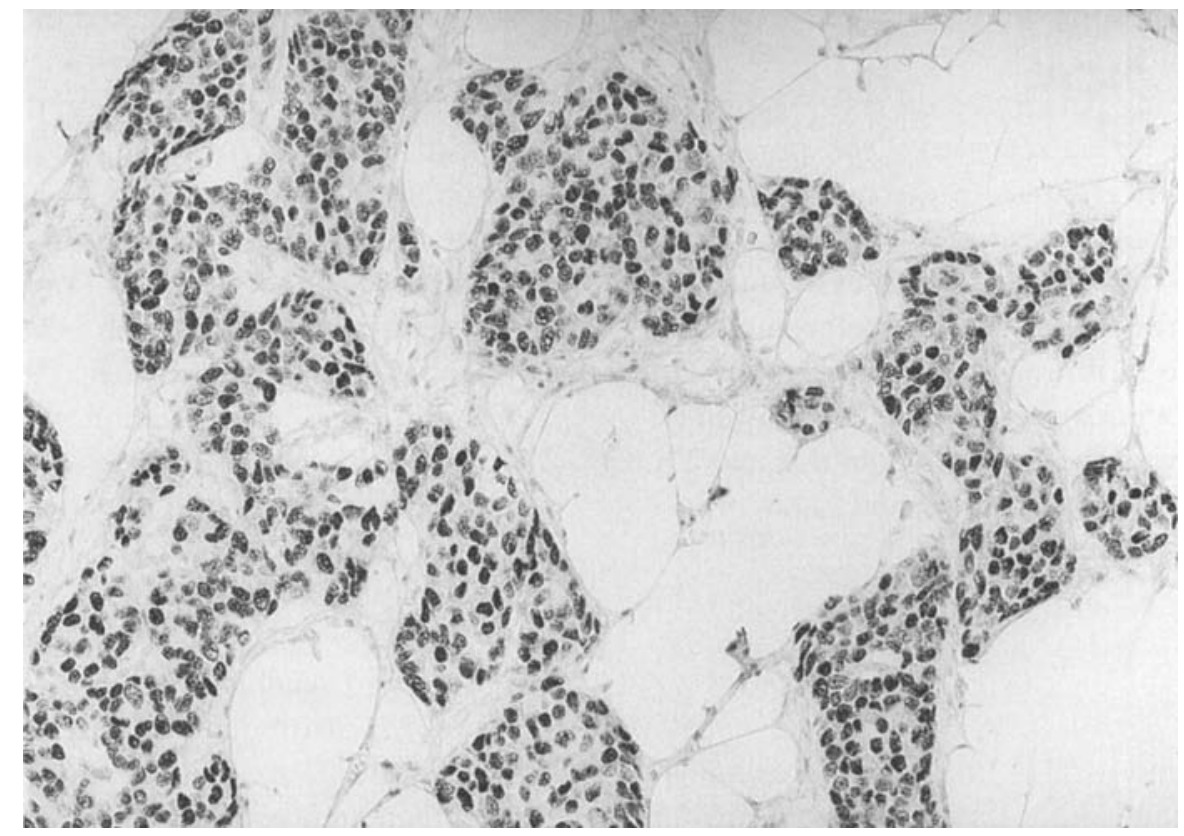

Figure 4. 'Carcinoid' tumour of the breast immunostained for ER. Most nuclei are positive for estrogen receptor (case 7). Objective $20 \times$.

sistent evidence that neuroendocrine cells produce ectopic hormones $[2,4,8]$, are additional arguments for the view that at least a proportion of the "carcinoids' of the breast are not true neuroendocrine tumours.

Currently, the presence of scattered (chromogranin A positive) neuroendocrine tumour cells within an infiltrating ductal carcinoma is attributed to a multidirectional differentiation of tumour cells during the neoplastic process $[2,28,29]$. In one case, an ER positive infiltrating ductal carcinoma with focal neuroendocrine differentiation, we showed the expression of ER in only a few chromogranin A positive cells; the bulk of chromogranin A positive cells was ER negative. This observation is comparable to the lack of AR in tumour cells with neuroendocrine differentiation in human prostatic carcinomas $[30$, 31].

Whatever hypothesis on the nature of carcinoids of the breast holds true, one of our cases represents a true neuroendocrine tumour in that all tumour cells are intensely argyrophylic associated with a strong chromogranin A expression in a small amount of tumour cells (Figures 2 and 4). The high expression of ER (Figure 3) and PR in this case clearly shows that neuroendocrine 'carcinoid' tu- mour of the breast may express sex steroid receptors like conventional breast carcinomas. Double staining confirmed the ER expression in chromogranin A reactive tumour cells in this case.

Our results with regard to sex steroid receptor expression indicate that 'carcinoids' of the breast have more in common with conventional breast cancer. As to the prognosis, this small series of 'carcinoids' of the breast seems to display a favourable biological behaviour, since all patients are alive two to five years after diagnosis. The low tumour stage similarly reflects a favourable prognosis. This is consistent with the view that 'carcinoids' of the breast should indeed be considered as well-differentiated carcinomas.

\section{References}

1. Nesland J, Memoli VA, Holm R, Gould VE, Johannessen JV: Breast carcinomas with neuroendocrine differentiation. Ultrastruct Pathology 8: 225-240, 1985

2. Fetissof F, Dubois MP, Arbeille-Brassart B, Lansac J, Jobard P: Argyrophillic cells in mammary carcinoma. Hum Pathol 14: $127-134,1983$

3. Monoghan P, Roberts JDB: Immunocytochemical evidence 
for neuroendocrine differentiation in breast carcinomas. J Path 147: 281-289, 1985

4. Taxy JB, Tischler AS, Insalaco SJ, Battifora H: 'Carcinoid" tumor of the breast: a variant of conventional breast cancer. Hum Pathol 12: 170-179, 1981

5. Azzopardi JG, Muretto P, Goddeeris P, Eusebi V, Lauweryns JM: Carcinoid tumours of the breast: the morphological spectrum of argyrophil carcinomas. Histopathol 6: 549569,1982

6. Partanen S, Syrjänen K: Argyrophilic cells in carcinoma of the female breast. Virchows Arch 391: 45-51, 1981

7. Toyoshima S: Mammary carcinoma with argyrophil cells. Cancer 52: 2129-2138, 1983

8. Bussolati G, Papotti M, Sapino A, Gugliotta P, Ghiringhello B, Azzopardi JG: Endocrine markers in argyrophilic carcinomas of the breast. Am J Surg Path 11(4): 248-256, 1987

9. Andreola S, Di Re E, Merson M, Maggiulli L, De Palma P: Immunohistochemical study of ten cases of argyrophilic carcinoma (carcinoid) of the breast. Tumori 74: 295-302, 1987

10. Kuenen-Boumeester V, Van der Kwast TH, Putten WLJ, Claassen C, van Ooijen B, Henzen-Logmans SC: Immunohistochemical determination of androgen receptors in relation to oestrogen and progesteron receptors in female breast cancer. Int J Cancer 52: 581-584, 1992

11. Lea OA, Kvinnsland S, Thorsen T: Improved measurement of androgen receptors in human breast cancer. Cancer Res 49: 7162-7167, 1989

12. Chabon $\mathrm{AB}$, Costales $\mathrm{F}$ : Estrogen receptor activity in primary argyrophil carcinoma of the breast. Diagn Gynecol Obstet 2: 93-97, 1980

13. Wong SY, Kernohan NM, Walker F: Breast cancers with extremely high oestrogen receptor protein status. Histopathology 16: 125-132, 1990

14. Hsu S, Raine L, Fanger H: Use of avidin-biotin-peroxidase complex $(\mathrm{ABC})$ in immunoperoxidase techniques: a comparison between $\mathrm{ABC}$ and unlabeled antibody (PAP) procedures. J Histochem Cytochem 29: 577-580, 1981

15. Shi S, Key M, Kalra K: Antigen retrieval in formaline-fixed, paraffin-embedded tissues: an enhancement method for immunohistochemical staining based on microwave oven heating of tissue sections. J Histochem Cytochem 39: 741-748, 1991

16. Taylor CR, Shi SR, Benjaporn C, Young L, Imam SA, Cote $\mathrm{RJ}$ : Strategies for improving the immunohistochemical staining of various intranuclear prognostic markers in formalin-paraffin sections: androgen receptor, estrogen receptor, progesterone receptor, p53 protein, proliferating cell nuclear antigen and Ki-67 antigen revealed by antigen retrieval techniques. Hum Pathol 25: 236-270, 1994

17. Zegers ND, Claasen E, Neelen C, Mulder E, Van Laar JH, Voorhorst MM, Berrevoets CA, Brinkmann AO, Van der Kwast TH, Ruizeveld de Winter JA, Trapman J, Boersma WJA: Epitope prediction and confirmation for the human androgen receptor: generation of monoclonal antibodies for multiassay performance following the synthetic peptide strategy. Biochem Biophys Acta 1073: 23-32, 1991

18. Janssen PJ, Brinkmann AO, Boersma WJ, Van der Kwast TH: Immunohistochemical detection of AR with monocional antibody F 39.4 in routinely processed paraffin-embedded human tissues after microwave pretreatment. J Histochem Cytochem 42: 1169-1175, 1994

19. Shi SR, Chaiwun B, Young L, Cote RJ, Taylor CR: Antigen retrieval technique utilizing citrate buffer or urea solution for immunohistochemical demonstration of androgen receptor in formaline-fixed paraffin sections. J Histochem Cytochem 41: 1599-1604, 1993

20. Iwamura M, Abrahamsson P, Benning CM, Cockett ATK, Di Sant'Agnese PA: Androgen receptor immunostaining and its tissue distribution in formaline-fixed, paraffin-embedded sections after microwave treatment. $\mathrm{J}$ Histochem Cytochem 42: 783-788, 1994

21. Grimelius L: A silver nitrate stain for $\alpha 2$ in human pancreatic islets. Acta Soc Med Upsal 73: 243-270, 1968

22. Stierer M, Rosen H, Weber R, Hanak H, Spona J, Tüchler H: Immunohistochemical and biochemical measurement of estrogen and progesteron receptors in primary breast cancer: correlation of histopathology and prognostic factors. Annals of surgery 218: 13-21, 1993

23. Clayton F, Ordonez NG, Sibley RK, Hanssen G: Argyrophilic breast carcinomas: evidence of lactational differentiation. Am J Surg Path 6(4): 323-333, 1982

24. McCutcheon J, Walker RA: The significance of argyrophilia in human breast carcinomas. Virchows Arch A 410:369-374, 1987

25. Anderson TJ, Battersby S: Correspondence: Argyrophilic and endocrine cells in breast cancer. Histopathol 9: 12471249,1985

26. Cross AS, Azzopardi JG, Krausz T, Van Noorden S, Polak JM: A morphological and immunohistochemical study of a distinctive variant of ductal carcinoma in situ of the breast. Histopathol 9: 21-37, 1985

27. Ferguson DJP, Anderson TJ: Distribution of dense core granules in normal benign and malignant breast tissue. $\mathrm{J}$ Pathol 147: 59-65, 1985

28. Gould VE: Histogenesis and differentiation: A re-evaluation of these concepts as criteria for the classification of tumours. Hum Pathol 17(3): 212-215, 1986

29. Delellis RA, Tischler AS, Wolfe HJ: Multidirectional differentiation in neuroendocrine neoplasms. J Histochem Cytochem 32(8): 899-904, 1984

30. Krijnen JLM, Janssen PJA, Ruizeveld de Winter JA, Van Krimpen H, Schröder FH, Van der Kwast TH: Do neuroendocrine cells in prostate cancer express androgen receptor? Histochemistry 100: 393-398, 1993

31. Bonkhoff H, Stein U, Remberger K: Androgen receptor status in endocrine-paracrine cell types of the normal hyperplastic, and neoplastic human prostate. Virchows Arch A 423: 291-294, 1993 